\title{
The heartbeat of a First Nation
}

$\mathrm{T}$ hose looking for an example of an instance in which genetics is revolutionizing modern heart medicine might not think first of the wildly beautiful area surrounding Gitxsan First Nation villages near the junction of the Bulkley and Skeena Rivers in northern British Columbia.

There among roughly 5400 members of the Gitxsan First Nation live many with ancestors who died young and suddenly. And unlike Newfoundland and Labrador, where meticulously maintained family trees in Bibles allowed researchers to trace suspected victims of a rare heart arrhythmia, a predominantly oral history does not allow much in the way of genealogical spadework.

"The Gitxsan have only had last names relatively recently, so you can only trace their families back to about the 1880s," says Laura Arbour, a geneti- cist at the University of British Columbia in Vancouver.

Yet, a series of recent developments has resulted in a diagnostic paradigm shift for a rare heart arrhythmia known as Long QT Syndrome, in which delayed repolarization of the heart following a heartbeat may occasionally result in fainting, palpitations and, in some instances, sudden death.

The syndrome was first clinically described in a family as early as the 1950s but it was notoriously difficult to differentiate Long QT's genetic roots from symptoms brought on by anxiety and stress, notes Dr. Charles Eckfeldt, a family physician at the Wrinch Memorial Hospital in Hazelton, BC. "And there is lots of anxiety around here due to the drug use and the alcohol abuse and blah, blah, blah."

But in 2008, a mutation specific to the Gitxsan, a known Long QT-causing gene, was discovered, shifting the diagnostic dynamic from probable carrier to almost-certain carrier.

"Finding the gene has unequivocally changed our practice" says Dr. Richard Leather, a cardiologist in Victoria. "Prior to genetic testing we only looked at the phenotype. Having actual firm genetics has helped a lot in saying you have the condition."

To date, more than 60 people in five extended Gitxsan families, or roughly 1 in 90 band members, have been diagnosed with the condition. In the general population, the incidence rate is estimated to be between 1 in 2000-10 000 .

Treatment is relatively simple: beta blockers and a less active lifestyle, particularly avoidance of such strenuous triggers as swimming.

Unlike the Newfoundland-specific version of arrhythmogenic right ventricular cardiomyopathy, however, carriers

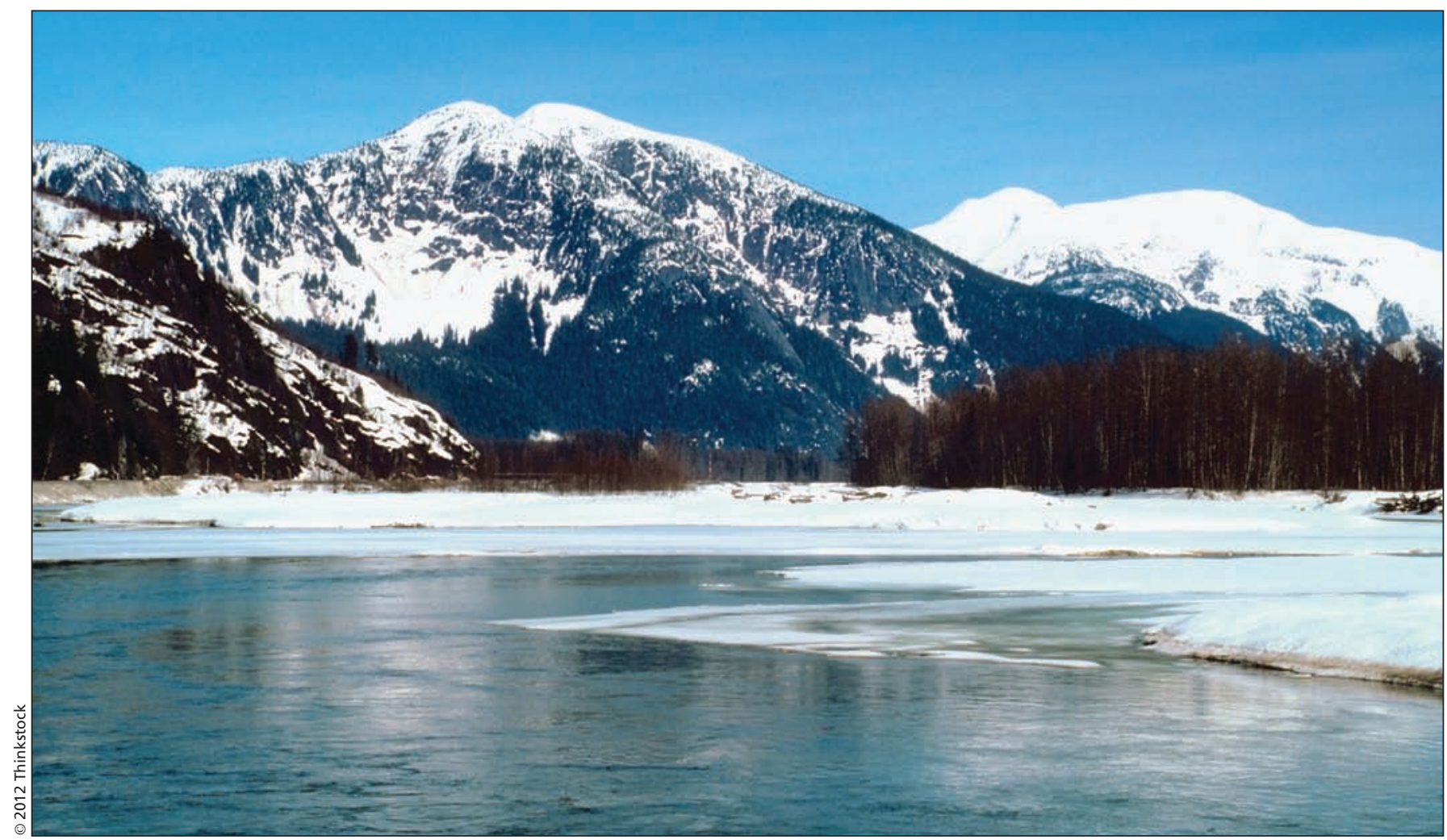

The Skeena is among the four rivers found in the 33000 square kilometres of traditional territory held by the roughly $\mathbf{5 4 0 0}$ members of Gitxsan First Nation. 
don't necessarily have one foot on a banana peel and the other in the grave, as the old adage goes. Cardiac arrest is the first clinical manifestation for about $15 \%$ of Long QT carriers. About 30\% are asymptomatic and for the remainder, symptoms such as fainting or heart palpitations are not necessarily linked to the gene.

Nonetheless, the discovery and the ability to test for the Gitxsan-specific mutation have had a dramatic impact on heart medicine in the area.

Genetic screening is expected to soon become routine for all the Gitxsan, "whether or not they have a relative with the disease or symptoms," Arbour says.

As importantly, some argue, is avoidance of medication that triggers the syndrome. A large variety of common medications, particularly congestion relievers such as diphenhydramine and epinephrine, are known to lengthen the QT interval, and thus raise cardiac risk among patients with Long QT. So physicians are able to select medications that lower the risk.

In aid of the latter cause, Peter Piddington, a pharmacist in Wrinch, has created a list of over 400 Long QTinterval-altering pharmaceuticals that takes into account nomenclature variations in Canada and the United States so as to prevent such mishaps as someone taking an unsuitable decongestant.

Social and cultural issues have also arisen. Gitxsan men, particularly those at high risk, seem to have a harder time accepting genetic testing to determine if they carry the mutation. Lee-Anna Huisman, a graduate student at UBC, notes that she was unable to recruit a single Gitxsan man to participate in traditional "talking circles" to discuss Long QT and its treatment. "When I asked they said that traditionally it was a woman's role to take care of the family."

That's similar to Newfoundland, where Kathy Hodgkinson, a clinical epidemiologist finds that men are typically reluctant to submit to genetic testing and it's often women in the family who press for screening.

That's particularly true with respect to children, Huisman says, noting that Gitxsan women "felt they could be strong for themselves, but they were mostly worried about children if they would test positive."
All of which raises the issue of whether gender or motherhood results in women's relationship to medical genetics being less abstract than that of men, and whether physicians must approach men differently when discussing genetic heart conditions. Arbour believes that's true. "I think what we are seeing has to do with gender notions and senses of who men are as men. It is the persona of strength." - Stephen Strauss, Toronto, Ont.

\section{CMAJ 2012. DOI:10.1503/cmaj.109-4103}

Second of a three part series:

Part 1: The rhythms of the Rock (www.cmaj.ca/lookup/doi/10.1503 /cmaj.109-4102).

Part 3: The all-clear signal for rare heart arrhythmias

(www.cmaj.ca/lookup/doi/10.1503 /cmaj.109-4104).

Stephen Strauss' research was made possible in part by a $\$ 20000$ Canadian Institutes of Health Research Journalism Award. 